\title{
Review of studies on land use and land cover change in Nepal
}

\author{
Basanta PAUDEL ${ }^{1,2}$ (D) http://orcid.org/oooo-0002-2485-089X; e-mail: paudelb@igsnrr.ac.cn

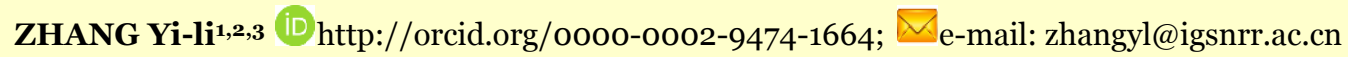 \\ LI Shi-cheng1,2 (D http://orcid.org/oooo-ooo1-6296-636X; e-mail: lisc.10s@igsnrr.ac.cn \\ LIU Lin-shan1 iD http://orcid.org/oooo-0oo2-0194-2214; e-mail: liuls@igsnrr.ac.cn \\ WU Xue1,2 (D http://orcid.org/oooo-ooo3-2346-306X; e-mail: wux.12s@igsnrr.ac.cn
}

Narendra Raj KHANAL4 iD http://orcid.org/oooo-0oo1-7945-8476; e-mail: nrkhanal.geog@gmail.com

\author{
1 Key Laboratory of Land Surface Pattern and Simulation, Institute of Geographic Sciences and Natural Resources \\ Research, Chinese Academy of Sciences, Beijing 100101, China \\ 2 University of Chinese Academy of Sciences, Beijing 10oo49, China \\ 3 CAS Center for Excellence in Tibetan Plateau Earth Sciences, Beijing 100101, China \\ 4 Central Department of Geography, Tribhuvan University, Kirtipur, Kathmandu 44613, Nepal
}

Citation: Paudel B, Zhang YL, Li SC, et al. (2016) Review of studies on land use and land cover change in Nepal. Journal of Mountain Science 13(4). DOI: 10.1007/s11629-015-3604-9

(C) Science Press and Institute of Mountain Hazards and Environment, CAS and Springer-Verlag Berlin Heidelberg 2016

\begin{abstract}
Land use and land cover (LULC) in Nepal has undergone constant change over the past few decades due to major changes caused by anthropogenic and natural factors and their impacts on the national and regional environment and climate. This comprehensive review of past and present studies of land use and land cover change (LUCC) in Nepal concentrates on cropland, grassland, forest, snow/glacier cover and urban areas. While most small area studies have gathered data from different sources and research over a short period, across large areas most historical studies have been based on aerial photographs such as the Land Resource Mapping Project in 1986. The recent trend in studies in Nepal is to focus on new concepts and techniques to analyze LULC status on the basis of satellite imagery, with the help of geographic information system and remote sensing tools. Studies based on historical documents, and historical and recent spatial data on LULC, have clearly shown an increase in cropland areas in Nepal,
\end{abstract}

Received: 23 June 2015

Revised: 17 September 2015

Accepted: 24 February 2016 and present results indicating different rates and magnitudes. A decrease in forest and snow/glacier coverage is reported in most studies. Little information is available on grassland and urban areas from past research. The unprecedented rate of urbanization in Nepal has led to significant urban land changes over the past 30 years. Meanwhile, long term historical LUCC research in Nepal is required for extensive work on spatially explicit reconstructions on the basis of historical and primary data collection, including LULC archives and drivers for future change.

Keywords: Land use; Land cover; Geographic information system; Remote sensing; Nepal

\section{Introduction}

Land use and land cover (LULC) is an obviously changing feature of the Earth's landscape, due to periodic natural and human modifications. 
There have been drastic changes in LULC over recent centuries (Houghton 2003). Efforts have been made to quantify the nature and extent of anthropogenic changes in land cover on national and local scales. The primary mode of humanmodified land use has been the conversion and modification of natural ecosystems for agriculture (Ramankutty and Foley 1999). The impact of humans on the environment is not a recent issue. In ancient times, there were many instances of harmful human activity affecting the Earth's landscape (Marsh 1864), and recent decades have provided valuable ideas, methods, tools and techniques to minimize impacts caused by LULC changes. Some researchers have conducted excellent work, documenting these historical changes globally (Ramankutty and Foley 1999; Pongratz et al. 2008) or nationally (LRMP 1986; Uddin et al. 2015). The process of land use and land cover change (LUCC) is very complex and takes different forms, with differences in magnitude and rate. Its dynamics vary according to its scale (Keyser and Kaiser 2010).

Nepal is a mountainous country, covering twothirds of the Himalayan region (Rokaya et al. 2012), where the main economic activities are based on agriculture. Nepal comprises five physiographic regions: High Mountain, Middle Mountain, Hill, the Shiwalik range and Tarai (LRMP 1986). The Middle Mountain and High Mountain regions are more sensitive to LUCC, and are more seriously affected by it, even with small changes, than the low land area of Tarai (Khanal 2002). This type of impact is not limited to regions where change takes place, but also easily spreads with further impact in the plains and low land areas, due to the high gradient of Nepal's mountain slopes (Becker and Bugmann 2001). In Nepal, the rate of forest land degradation and increase in cropland has been very high since the 1970s; this has created many problems for economic development, human activities and the overall environment (Collins and Jenkins 1996). According to the theory of Himalayan Environmental Degradation, high population growth rate, economic activities based on natural resources and poverty have caused mass forest degradation and have had an adverse effect on the environment (Ives and Messerli 1989); this relates directly to LUCC issues in Nepal. There are a number of studies on the causes, pathways and pace of LUCC, as regards cropland, forest, grassland, snow/glacier cover and urban land in various areas of Nepal (Bajracharya 1983; Mahat 1985; Mahat et al. 1986; Virgo and Subba 1994; Shrestha and Brown 1995; Khanal 2002; Sharma 2003; Khanal and Watanabe 2006; Bajracharya et al. 2014; Uddin et al. 2015). Forms of land use such as grazing, shifting cultivation, deforestation, urbanization and land degradation have also been major players in LUCC in the past. The processes of LULC in terms of their magnitude, pathways and drivers are very dynamic and change rapidly over space and time.

In recent decades, Nepal's population has grown rapidly. As more people have required increasing amounts of food and commodities from agriculture and natural resources, this period inevitably has seen cropland expansion at an unprecedented pace, forest land degradation, urban land expansion and the decline of grassland and snow/glacier cover due to climatic effects, all of which are directly related to LUCC issues. The main aim of this paper is therefore to explain the past status and recent trends of LUCC in Nepal and to indicate the composition and distribution of major LULC types.

\section{Study Area, Sources of Data and Methods}

This paper covers the whole of Nepal, which is situated at latitudes $26^{\circ} 22^{\prime}-30^{\circ} 27^{\prime} \mathrm{N}$ and longitudes $80^{\circ} 04^{\prime}-88^{\circ} 12^{\prime} \mathrm{E}$ and which shares borders with China to the north and India to the east, south and west (Figure 1). Nepal has a total land area of $147,181 \mathrm{~km}^{2}$ and a population of 26.4 million (CBS 2012). More than $80 \%$ of the country is mountainous (Shrestha and Zinck 2001), with elevations ranging from 60 meters above mean sea level ( $\mathrm{m}$ asl) in the southern plains to $8848 \mathrm{~m}$ asl on Mount Sagarmatha (Qomolangma/Everest) in the north, which is the highest point on Earth (LRMP 1986). Administratively, Nepal has 14 zones and 75 districts with five development regions (CBS 2012).

The present study uses various datasets and documents, which are listed in Tables 1 and 2 and the references section. Available details on LULC datasets are also presented. The collected datasets 


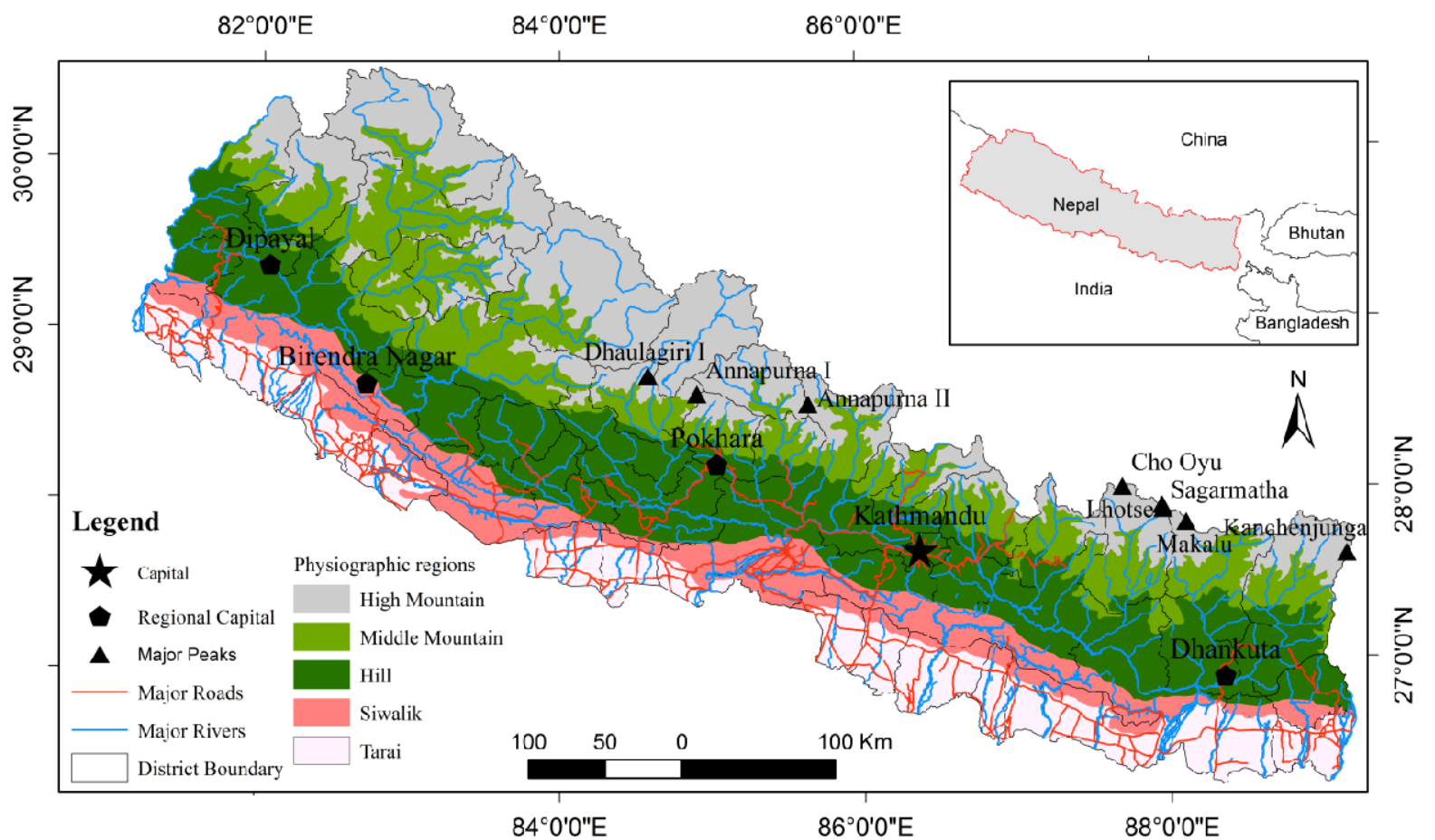

Figure 1 Physiographic and administrative distribution of study area (Nepal).

Table 1 List of country-scale land use and land cover (LULC) data sources and mapping in Nepal

\begin{tabular}{|c|c|c|c|c|}
\hline Research types & Spatial coverage & Data resources & Temporal coverage & Sources / References \\
\hline LUCC & Whole of Nepal & Aerial photographs & $1978 / 79$ and $1985 / 86$ & (Nield 1985) \\
\hline LULC & Whole of Nepal & Aerial photographs & $1978 / 79$ & (LRMP 1986) \\
\hline LULC & Whole of Nepal & Aerial photographs & 1986 & (MPFS 1989a, 1989b) \\
\hline Topographical map & Whole of Nepal & Aerial photographs & 1989 to 2001 & (Chhatkuli 2004) \\
\hline Forest land (NFI) & Whole of Nepal & $\begin{array}{l}\text { Aerial photographs, } \\
\text { Landsat satellite imagery }\end{array}$ & 1990-1994 & (Gautam et al. 2004) \\
\hline Forest land (FSRO) & Whole of Nepal & Aerial photographs & $1953-58$ and $1963 / 64$ & $\begin{array}{l}\text { (Acharya and Dangi } \\
\text { 2009) }\end{array}$ \\
\hline Snow cover & Whole of Nepal & Satellite imagery & 2000-2005 & $\begin{array}{l}\text { (Shrestha and Joshi } \\
\text { 2009) }\end{array}$ \\
\hline Glacier cover & Whole of Nepal & $\begin{array}{l}\text { Aeirial photographs, Topo } \\
\text { map and satellite imagery }\end{array}$ & 2001 and 2010 & $\begin{array}{l}\text { (Bajracharya et al. } \\
\text { 2011) }\end{array}$ \\
\hline Glacier cover & Whole of Nepal & Landsat satellite imagery & $\begin{array}{l}\text { 1980, 1990, } 2000 \text { and } \\
2010\end{array}$ & $\begin{array}{l}\text { (Bajracharya et al. } \\
\text { 2014) }\end{array}$ \\
\hline Land cover & Whole of Nepal & Landsat satellite imagery & 2010 & (Uddin et al. 2015) \\
\hline Land cover & Global & Landsat satellite imagery & 2010 & (Chen et al. 2015) \\
\hline
\end{tabular}

represent the overall status of spatial and nonspatial LULC datasets in Nepal. These datasets have been obtained from sources such as web sites and academic and research institutions. Most of the scientific research documents have been obtained from web sites. Some were collected from the central library of Tribhuvan University, Nepal; the International Center for Integrated Mountain Development (ICIMOD), Nepal; and various governmental offices. The spatial datasets of LULC for 1978 and 2010 were obtained from ICIMOD
Nepal. The details of all datasets used in this paper are listed in Tables 1 and 2, which show dataset types, spatial and temporal coverage and author names. In all cases, most research is concerned with forestland and snow/glacier cover change; little information is available for crop, urban and grassland areas.

Simple methods and techniques are used in this paper for processing and analyzing the available data. This research was conducted using four steps (Figure 2) for the sake of clear 
Table 2 List of regional, district, watershed and local-level land use and land cover (LULC) data sources and mapping in Nepal

\begin{tabular}{|c|c|c|c|c|}
\hline Research types & Spatial coverage & Data resources & Temporal coverage & Sources / References \\
\hline LUCC & Karnali zone & Landsat imagery & 1950 and 1972 & (Bishop 1990) \\
\hline LUCC & Upper Pokhara valley & $\begin{array}{l}\text { Toposheet, land utilization } \\
\text { and land use map }\end{array}$ & 1957, 1978 and 1989 & (Thapa and Weber 1990) \\
\hline LULC & Dhankuta district & Aerial photographs & 1978 and 1990 & (Virgo and Subba 1994) \\
\hline LULC & Roshi watershed & Maps, aerial photographs & $\begin{array}{l}1947,1972,1978 / 79 \\
\text { and } 1990\end{array}$ & $\begin{array}{l}\text { (Shrestha and Brown } \\
\text { 1995) }\end{array}$ \\
\hline $\begin{array}{l}\text { Land use, land } \\
\text { management }\end{array}$ & Seti river basin & Aerial photographs & 1996 & (Thapa 1996) \\
\hline $\begin{array}{l}\text { LULC and } \\
\text { climate change }\end{array}$ & Koshi basin & $\begin{array}{l}\text { Satellite images and } \\
\text { modeling approaches }\end{array}$ & 2000 & (Sharma et al. 2000) \\
\hline LUCC & Madi watershed & $\begin{array}{l}\text { Aerial photographs, satellite } \\
\text { imagery }\end{array}$ & $1956-1996$ & (Khanal 2002) \\
\hline LUCC & Roshi watershed & Satellite imagery & $\begin{array}{l}1976,1989 \text { and } \\
2000\end{array}$ & (Gautam et al. 2003) \\
\hline Forest cover & 20 Tarai district & Satellite imagery & 1990/91-2000/01 & (Gautam et al. 2004) \\
\hline Snow cover & $\begin{array}{l}\text { Sagarmatha national } \\
\text { park }\end{array}$ & $\begin{array}{l}\text { Aeirial photographs and } \\
\text { satellite imagery }\end{array}$ & 1978 to 2009 & (Midriak 2009) \\
\hline Snow cover & Nepal log. $80^{\circ} \mathrm{E}-89^{\circ} \mathrm{E}$ & MODIS & 2000 to 2008 & (Maskey et al. 2011) \\
\hline $\begin{array}{l}\text { LUCC and } \\
\text { climate change }\end{array}$ & Koshi basin & Satellite imagery & 1992-2010 & (Gao 2012) \\
\hline Snow cover & Dudh Koshi basin & MODIS and model & 2002-2003 & (Shrestha et al. 2012) \\
\hline Snow cover & Marsyangdi river area & $\begin{array}{l}\text { Topo map and satellite } \\
\text { imagery }\end{array}$ & 1995-2007 & (Kuhle 2014) \\
\hline Snow cover & Dudh Koshi basin & $\begin{array}{l}\text { Satellite imagery and } \\
\text { modeling }\end{array}$ & $1961-2007$ & (Shea et al. 2014) \\
\hline Urban land & Kathmandu valley & $\begin{array}{l}\text { Satellite imagery and } \\
\text { modeling }\end{array}$ & $\begin{array}{l}\text { 1991-2010 and } \\
\text { prediction to } 2050\end{array}$ & $\begin{array}{l}\text { (Thapa and Murayama } \\
\text { 2012) }\end{array}$ \\
\hline
\end{tabular}

presentation. First, all available past LULC datasets and research documents were collected. Second, these datasets and materials were categorized into major LULC classes such as cropland, grassland, forest, urban land and snow/glacier cover. The first part of step there was that the spatial datasets were

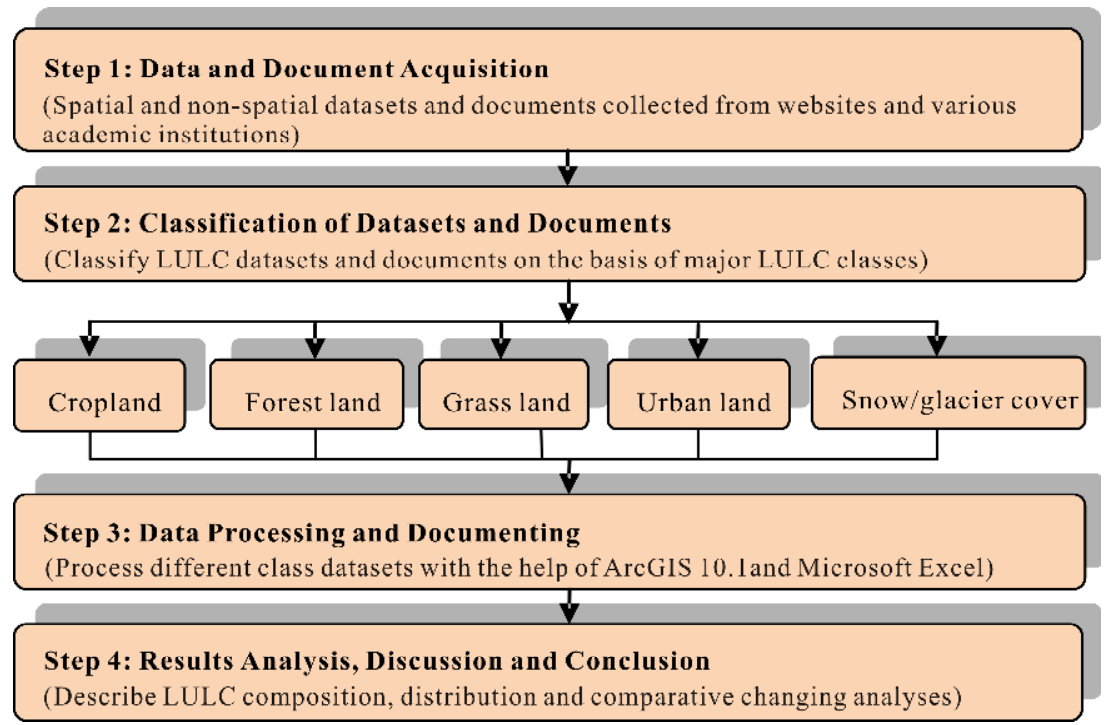

Figure 2 Algorithm of the study. processed with the help of ArcGIS 10.1 and Microsoft Excel tools; second part of this stage consisted of summarizing the LULC historical documents on the basis of their findings and results. The final step was to analyze Nepal's overall past LULC composition, distribution, changing scenarios and problems in various areas, on the basis of the processed spatial datasets, historical research, documents and statistical records.

\section{Achievements}

\subsection{LULC mapping}

With regard to the overall historical records of the sectors of LULC mapping in Nepal, the first attempt was made in 1964 by the forest resource survey office (FRSO) in the form of 
forest cover mapping on the basis of $1953-58$ and 1963-64 aerial photographs at the national level. That project mapped forest land using visual interpretation of aerial photographs with field verification, with the forest categorized into commercial and noncommercial forest (Acharya and Dangi 2009). Aerial photographs (1978/79 and 1985) were the basis of another national-scale mapping of forest cover change conducted as a major part of LULC in 1985 (Nield 1985).

The first detailed LULC mapping was carried out in 1986 by the Land Resource Mapping Project (LRMP), which created a number of datasets (geology, land system, land utilization and land capability) on the basis of 1978/79 aerial photographs at a scale of 1:50,000 (LRMP 1986). It mapped all LULC categories with reports on each aspect. On the basis of LRMP records and forest data from FRSO, the Ministry of Forests implemented a master plan for the forestry sector (MPFS) in 1986, which was mainly designed to update the LRMP information (MPFS 1989a; 1989b). The Nepal government survey department prepared and published a topographical map of Nepal based on aerial photographs taken in 1989 for the eastern part, and in 1996 for the western part of the country, at two different scales (1:25,000 in Tarai and the Hill area and 1:50,000 in the Mountain area) (Chhatkuli 2004). This showed different categories of LULC for the whole country. The National Forest Inventory (NFI) was launched in 1990 to measure forestland change and was completed in 1994 (Gautam et al. 2004). NFI used Landsat satellite imagery, aerial photographs and field measurements to discover forest change scenarios in Nepal. National-level detailed land cover mapping has recently been completed (Uddin et al. 2015), and a land cover database of Nepal was developed in 2010 using Landsat TM 30m resolution satellite imagery. Major national-level mapping of LULC is set out in Table 1.

In addition, there have been attempts to map LULC in Nepal on the scale of regions, districts, watersheds, river basins and micro-areas. Some of these have been, published and some are unpublished reports or thesis work. Most research in Nepal has used aerial photographs and satellite imagery for LULC mapping at watershed and river basin levels. An LULC map was developed in the Madi watershed in 2002 and assessed LUCC scenarios of 1956-1996 (Khanal 2002). Another satellite imagery-based forest cover mapping of Tarai's 20 districts was carried out by the Department of Forest and Soil Conservation in 2005 (MoFSC 2009), covering the periods 1990/91 and 2000/01. Similarly, satellite imagery-based mapping of the Koshi river basin was carried out in 2000 (Sharma et al. 2000) and 2012 (Gao 2012). These two studies presented detailed mapping of LULC in 1992, 2000 and 2010 in the Koshi river basin.

The majority of snow cover and glacier mapping in Nepal was carried out by the ICIMOD. The decadal national-level mapping for different periods (1980, 1990, 2000 and 2010) was carried out on the basis of Landsat 5MMS, 7TM and 7ETM+ images (Bajracharya et al. 2014). More snow cover mapping was carried out in 2009, which presented the national-level status of snow cover from 2000 to 2005 (Shrestha and Joshi 2009). These mapping exercises indicated that remote-sensing (RS) data and geographic information system (GIS) tools are more reliable for snow cover mapping. Further snow cover and glacier change research has been carried out using various methods, datasets and techniques in Nepal in a major part of the Himalayan regions (Armstrong 2010; Bajracharya and Shrestha 2011; Bolch et al. 2012), as well as at the national level (Shrestha and Joshi 2009; Bajracharya et al. 2011; Bajracharya et al. 2014) or at a smaller scale (Maskey et al. 2011; Shrestha et al. 2012; Kuhle 2014; Shea et al. 2014). The overall small-scale mapping of various classes of LULC in Nepal is summarized in the Table 2, with LULC categories, spatial and temporal coverage, sources of data and references.

\subsection{LULC composition and distribution}

\subsubsection{Overall composition and distribution}

The current LULC composition presented in the national-level study of Nepal estimates the distribution of land in Nepal as $39.1 \%$ forest, $29.83 \%$ cropland, $7.90 \%$ grassland, $8.20 \%$ snow/glacier cover, $3.40 \%$ shrub land and $10.65 \%$ barren land (sand, gravel and rock). Lakes and rivers cover $0.60 \%$ of land, and built-up areas comprise 0.32\% (Figure 3) (Uddin et al. 2015). 
The detailed distribution patterns of Nepal's LULC vary according to physiographic region. Cropland is shown to cover an area of only $0.50 \%$ in the High Mountains region, as compared with $12.04 \%$ in the Middle Mountains, and 45.05\%, $10.74 \%$ and $32.12 \%$ in the Hill, Siwalik and Tarai regions respectively. The distribution of natural vegetation including forest, grassland and shrub also

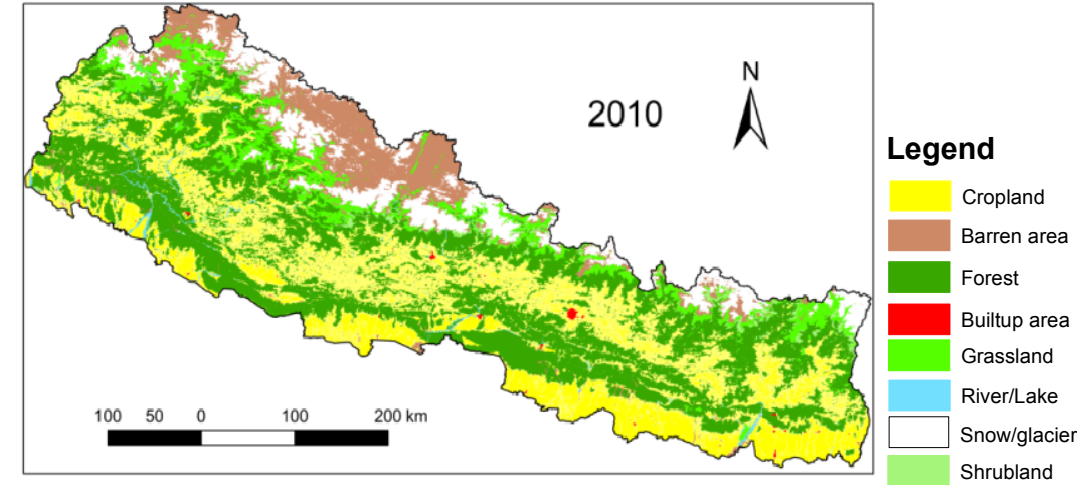

Figure 3 Land use and land cover (LULC) in Nepal 2010 (Uddin et al. 2015). varies according to the physiographic region, with $13.03 \%, 32.55 \%, 30.50 \%, 18.15 \%$ and $5.77 \%$ for these same five regions, respectively.

Nepal's territory is a major part of the Himalayan region, which is mostly mountainous and has a large area of snow/glacier. Of the total snow/glacier cover, the High Mountain region accounts for over 95\% area. The barren land distribution of the country is generally similar to snow/glacier cover. The majority of barren land is distributed (83.59\%) in the High Mountain region, with the Tarai region in second position (8.46\%). Patterns of the distribution of artificial surfaces and built-up areas differ from those of the other land categories, being mostly concentrated in the Hill and Tarai regions, where they account for $42.69 \%$ and $40.33 \%$, respectively, of the total builtup area (Uddin et al. 2015).

On the basis of the national-level LULC dataset, we conclude that the major types of LULC in Nepal are forest land, cropland, grassland, snow/glacier cover and urban areas. Forest land (including other natural vegetation) is mainly concentrated in the Tarai and Hill regions of Nepal, while the majority of cropland is in the southern (Tarai) and middle part (Hill region) of the country. The current scenario is different for snow/glacier cover, which is mostly located in the northern part (High Mountain region) of Nepal.

\subsubsection{Land use and land cover change}

Various studies, using different methods and techniques, have presented changing scenarios of LULC in Nepal. Over the past 30 years, the results of detailed research show that forest land decreased during the middle ten years (spanning the 1980s and 1990s) (Gautam et al. 2004) but that it recovered (+1.01\%) between $1978 / 79$ and 2010 (LRMP 1986; Uddin et al. 2015). Cropland slightly increased $(+2.64 \%)$ overall, while grassland declined over the same period. However, on the contrary, snow/glacier cover showed a $4.61 \%$ increase between these periods. Forest land, in particular, increased in the middle of the country (Hill region and Siwalik), while in some parts of the Tarai region it slightly decreased. Grassland declined $(-3.64 \%)$ in the Hill, Middle Mountain and High Mountain areas (LRMP 1986; Uddin et al. 2015).

Over the past 30 years, the conversion statuses of different LULC classes had different magnitude and rates. In this period, there has been significant conversion between forest land to cropland and from cropland to urban land. The details of LULC conversion statistics between 1978/79 and 2010 are shown in Table 3. The conversion rate between snow/glacier cover and grassland has also been very high. However, statistics show no conversion between cropland and snow/glacier cover, or between urban land and snow/glacier cover.

Historical LULC research in Nepal is limited to descriptions in the form of books and reports. No spatial datasets were created before the 1960s. Since the 1960s, there has been satisfactory progress in land resource research in Nepal. Historical documents mention the patterns and processes of LUCC for different periods (Regmi 1976; 1978; Mahat 1985; Nield 1985; Kirkpatrick 1996). Some aspects of LUCC patterns in the $18^{\text {th }}$ century were briefly described by the foreign visitor Colonel Kirkpatrick, in 1793, during his research visit along the north-south transect from Tarai to Kathmandu and Nuwakot in the Middle Hills in Nepal (Kirkpatrick 1996). He observed that the 
Table 3 Land use and land cover (LULC) conversion statistics between 1978/79 (LRMP 1986) and 2010 (Uddin et al. 2015). The shade area indicates no change within respective class.

\begin{tabular}{|c|c|c|c|c|c|c|c|c|c|}
\hline $\begin{array}{l}\text { Land cover } \\
\left(\mathrm{km}^{2}\right)\end{array}$ & Cropland & $\begin{array}{l}\text { Forest } \\
\text { land }\end{array}$ & $\begin{array}{l}\text { Grass } \\
\text { land }\end{array}$ & $\begin{array}{l}\text { Urban } \\
\text { land }\end{array}$ & $\begin{array}{l}\text { Shrub } \\
\text { land }\end{array}$ & $\begin{array}{l}\text { Snow/glacier } \\
\text { cover }\end{array}$ & Other & $\begin{array}{l}\text { Total } \\
(1978 / 79)\end{array}$ & $\begin{array}{l}\% \\
(1978 / 79)\end{array}$ \\
\hline Cropland & 27966 & 8991 & 762 & 354 & 671 & O & 1275 & 40019 & 27.19 \\
\hline Forest land & 9819 & 41597 & 1732 & 21 & 2061 & 11 & 703 & 55944 & 38.01 \\
\hline Grassland & 3098 & 2995 & 4729 & 10 & 944 & 747 & 4462 & 16985 & 11.54 \\
\hline Urban land & 40 & 2 & 3 & 72 & 0 & o & 5 & 122 & 0.08 \\
\hline Shrub land & 1839 & 3231 & 516 & 2 & 373 & 25 & 902 & 6888 & 4.68 \\
\hline $\begin{array}{l}\text { Snow/glacier } \\
\text { cover }\end{array}$ & o & 2 & 110 & o & 6 & 4441 & 725 & 5284 & 3.59 \\
\hline Other & 1148 & 719 & 3782 & 10 & 953 & 6838 & 8489 & 21939 & 14.91 \\
\hline Total (2010) & 43910 & 57537 & 11634 & 469 & 5008 & 12062 & 16561 & 147181 & 100 \\
\hline$\%(2010)$ & 29.83 & 39.09 & 7.91 & 0.32 & 3.4 & 8.2 & 11.25 & 100 & \\
\hline
\end{tabular}

mountain slopes, although steep, were cultivated from their summit to their base. This is the first research document on the LULC status of Nepal. Many years later, a historical-document-based review was carried out by Regmi for a different period (Regmi 1976; 1978); he presented the fluidity of forest, shrub and cropland, and the productivity of crops between 1768 and 1970. This review shows how political instability and frequent changes in government policies regarding land ownership rights, labor utilization and taxation caused the fluidity in land use and the production of crops in the country. A review of national-level and district-level historical documents shows that forest land degradation started in Nepal in the late $18^{\text {th }}$ century. Government policies focused on gaining revenue from natural resources and agriculture; dry land was used for crops, which caused a high rate of forest degradation and an expansion of cropland during the $18^{\text {th }}$ century in the Middle Hills region (Mahat 1985). In 1985 Nield estimated the changes in broad land cover types by physiographic region in the country between 1978/79 and 1985. The High Mountain and the Middle Mountain experienced increases in forest area of $0.07 \%$ and $0.13 \%$ per year, respectively (Nield 1985).

The changing status of the forest area has been reported in several studies carried out for different periods and using different methods (LRMP 1986; Gautam et al. 2004; Acharya and Dangi 2009; Uddin et al. 2015). The data on the area covered by forest provided by various studies between 1964 and 2010 show a net decline until the end of the $20^{\text {th }}$ century. After 2000, the level recovered slightly (Khanal 2002) and it is currently $39.1 \%$ (Uddin et al. 2015). Most national and small-scale studies of snow/glacier change have reported that snow cover in recent decades is rapidly changing (Fujita et al. 1997; Bajracharya et al. 2011; Bajracharya et al. 2014). It is also reported that former areas of snow cover have become bare ground.

Some studies have focused on the LUCC of small areas for different periods and places in Nepal (Bishop 1990; Thapa and Weber 1990; Katwal and Sah 1992; Fox 1993; Shrestha and Brown 1995; Thapa 1996; Sharma et al. 2000; Khanal 2002; Gautam et al. 2003; Khanal and Watanabe 2006). The forest area in the Karnali zone in Nepal declined by 50\% between 1950 and 1972, while cropland increased by $54.9 \%$ (Bishop 1990). Between 1976 and 2000 the typical mountain watershed in Kavrepalanchok district (Roshi watershed), a total area of 15335.2 ha, showed an increase in forest cover areas (5339.3, 5786.1 and 6133.3 ha, respectively), and a decrease in grassland and upland crop areas (471.6, 236.5, 197.1 and 6627.4, 6578, 6139.4 ha, respective) from 1976, 1989 and 2000 (Gautam et al. 2003). Similarly, between 1947 and 1981 there was a 24\% decrease in forest cover, a 10\% increase in cropland and a $14 \%$ increase in shrub land; and between 1972 and 1990 there was increase (5496 to $6073 \mathrm{ha}$ ) in cropland and significant decrease in grassland (1184 to 466 ha) in Jhikhu watersheds of the mountainous regions in Nepal (Shrestha and Brown 1995). However, no significant changes in major land use categories, such as crop and noncropland areas, were observed over a 12-year period (1978-1990) in the Middle Mountain zone in the Dhankuta district (Virgo and Subba 1994). Improvements in forest cover between 1980/81 and 1990 were reported from Bhokteni village in 
the Gorkha district (Fox 1993). Some studies have covered the changing relationship of climate and LULC (Sharma et al. 2000), human activities on LUCC (Thapa 1996) and overall LULC status (Thapa and Weber 1990) in small mountainous regions of Nepal.

\subsubsection{Composition, distribution and change of major LULC classes}

\section{Cropland change}

A number of studies have been carried out on cropland change in Nepal. Several global-level studies cover Nepal's cropland changes from historic times to recent decades (Ramankutty and Foley 1999; Goldewijk 2001; Goldewijk and Ramankutty 2004; Pongratz et al. 2008; Goldewijk et al. 2011; Goldewijk and Verburg 2013). Countrylevel details of spatial LULC research are limited (LRMP 1986; Uddin et al. 2015), and cover cropland change scenarios for only the past 32 years. In this study, cropland is regarded as agricultural land that is actively being farmed.

Analyzing former cropland change in Nepal, Nield (1985) gave the annual rate of increase in cropland as $0.37 \%$ in the High Mountains, $0.01 \%$ in the Middle Mountains, $0.56 \%$ in Siwalik and $0.85 \%$ in Tarai, while it decreased by $0.02 \%$ in the High Mountain region between $1978 / 79$ and 1985 . Country-level research and datasets show that the cropland area in Nepal was $27.19 \%\left(40,019 \mathrm{~km}^{2}\right)$ in 1978/79 (Figure 4a) (LRMP 1986). A recent satellite-based study (Uddin et al. 2015) reported the condition of cropland in 2010 as being slightly increased at $29.83 \%\left(43,910 \mathrm{~km}^{2}\right)$ (Figure $\left.4 \mathrm{~b}\right)$ of the total area of Nepal; this was $2.64 \%$ greater than scenarios over the past 32 years. If this is compared to the result of LRMP (1986) and Uddin et al. (2015), it is clear that there have been more changes in the middle part of the country, which is a mostly hilly region, from a physiographical point of view. This means that changes in cultivation patterns and practices are not concentrated in only the plain area, but also occur at high elevations too.

Spatial studies over past the 30 years in Nepal illustrate that, there have been slightly increased cropland; however, the statistical datasets of the Food and Agriculture Organization (FAO) show the rate of cropland change rapidly increasing from 1961 to 2001, then slightly decreasing until 2010/11 (FAO 2014). The value for cropland in Nepal was
4126.6 ('o0o ha) as of 2011 (FAO 2014). As the graph of FAO data (Figure 5) shows, over the past 50 years the indicator reached a maximum value of 4261('ooo ha) in 2001 and a minimum value of 3553 ('ooo ha) in 1961. This means that, between these dates, cropland increased by around $13 \%$, the rate of which was significantly higher than the spatial study of LRMP (1986) and Uddin et al. (2015) between 1978/79 and 2010. It shows that, there have vast methodological differences in the spatial and non-spatial calculation of cropland studies in Nepal. Similarly, the comparison of the global spatial datasets of HYDE 3.1 (Goldewijk et al. 2011) and the national-level statistical datasets of the Food and Agriculture Organization (FAO 2014) shows that (Figure 5) almost double the area is shown in the statistically based national-level data.
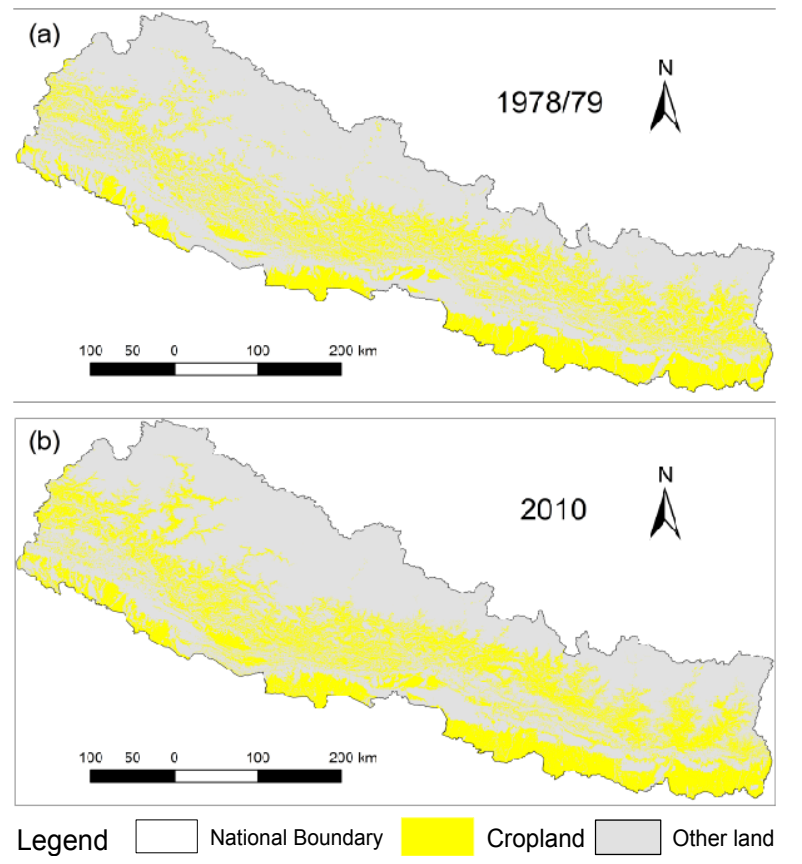

Figure 4 Cropland area in Nepal (a) 1978/79 (LRMP 1986) and (b) 2010 (Uddin et al. 2015).

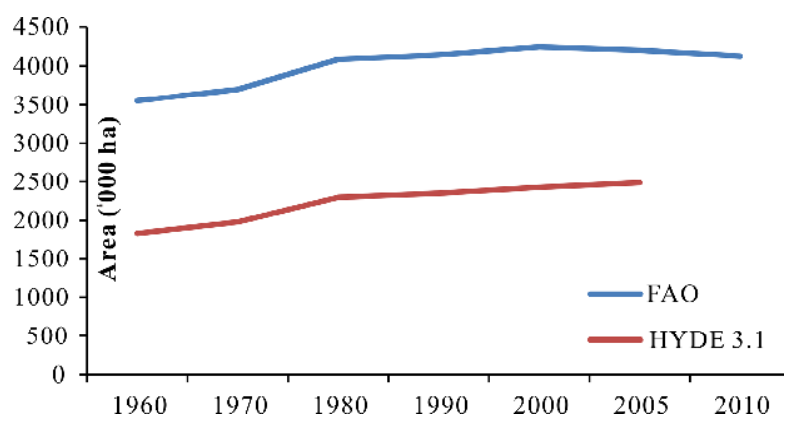

Figure 5 Cropland area in Nepal 1960 to 2010. 
This represents a vast difference between globallevel spatial datasets and national level-statistical datasets, so future studies should reconstruct historical cropland change in Nepal on the basis of available national-level statistical and spatial datasets, because global-level datasets do not reflect well the national-level LULC conditions and status.

\section{Grassland change}

Grassland ecosystems, which are areas where the vegetation is dominated by grasses, are important resources for humans and a major component of the terrestrial ecosystem (Zhang et al. 2014). Historically, many generations have regarded grassland as a major resource for livestock rearing in Nepal (Sharma 2006), and they have developed a number of sedentary and migratory grazing systems. Grassland in Nepal is categorized according to zones on the basis of climate: tropical, sub tropical, temperate, subalpine or alpine. Because of the harsh climatic conditions, poor management and overgrazing, grass land areas have changed significantly and have degraded to an alarming extent. This type of land is less productive than well-managed grassland, but it is an essential part of livestock farming systems in Nepal. The condition and status of grassland in Nepal at the national-level was reported as 11.4\% in 1978/79 (LRMP 1986) (Figure $6 a$ ), and such land occurred in subtropical regions, medium hills, high mountainous valleys, the inner Himalayan range and alpine regions. Grasslands are mostly concentrated in the mountainous region in Nepal, and only $4 \%$ is found at low elevations.

Due to the high pressure of grazing requirements, grasslands have undergone continuous change (LRMP 1986; Uddin et al. 2015). Grassland decreased in recent decades and was only $7.90 \%$ of the whole area of Nepal in 2010 (Uddin et al. 2015) (Figure 6b). Due to an increase in human and livestock populations, and constant overgrazing, as well as the cutting down of woody vegetation, grasslands in Nepal have seriously deteriorated. Research also shows that in the Himalayan regions, nomadic farming practices have been abandoned and people's occupations have now changed due to partly the declining amount of grassland, and partly government grassland conservation policies (Hua et al. 2013).

Forest land change
In Nepal forest land is an essential part of the farming system (Acharya and Dangi 2009), and is understood as being the area covered by trees or other woody vegetation. Most farmers use forests, and in their daily lives, they have access to forest products such as fuel wood, leafy biomass and timber. This has had a direct bearing on forest land change (Mahat 1987; Gilmour and Fisher 1991; Malla 2000). It is estimated that in the highaltitude mountainous zones of Nepal, 1 ha of cropland requires around 50 ha of forest and grassland (Whiteman 1985); this means that expansion of cropland is directly related to forest and grassland degradation in mountainous regions.

Many studies of forest land have been carried out in Nepal since the 1960s (FRA 2010) (Table 4). The FRSO survey estimated that forest comprised $43.5 \%$ of the total land area in Nepal in 1964 (Acharya and Dangi 2009), where as LRMP reported $38.1 \%$ for $1978 / 79$ (Figure $7 \mathrm{a}$ ) (LRMP

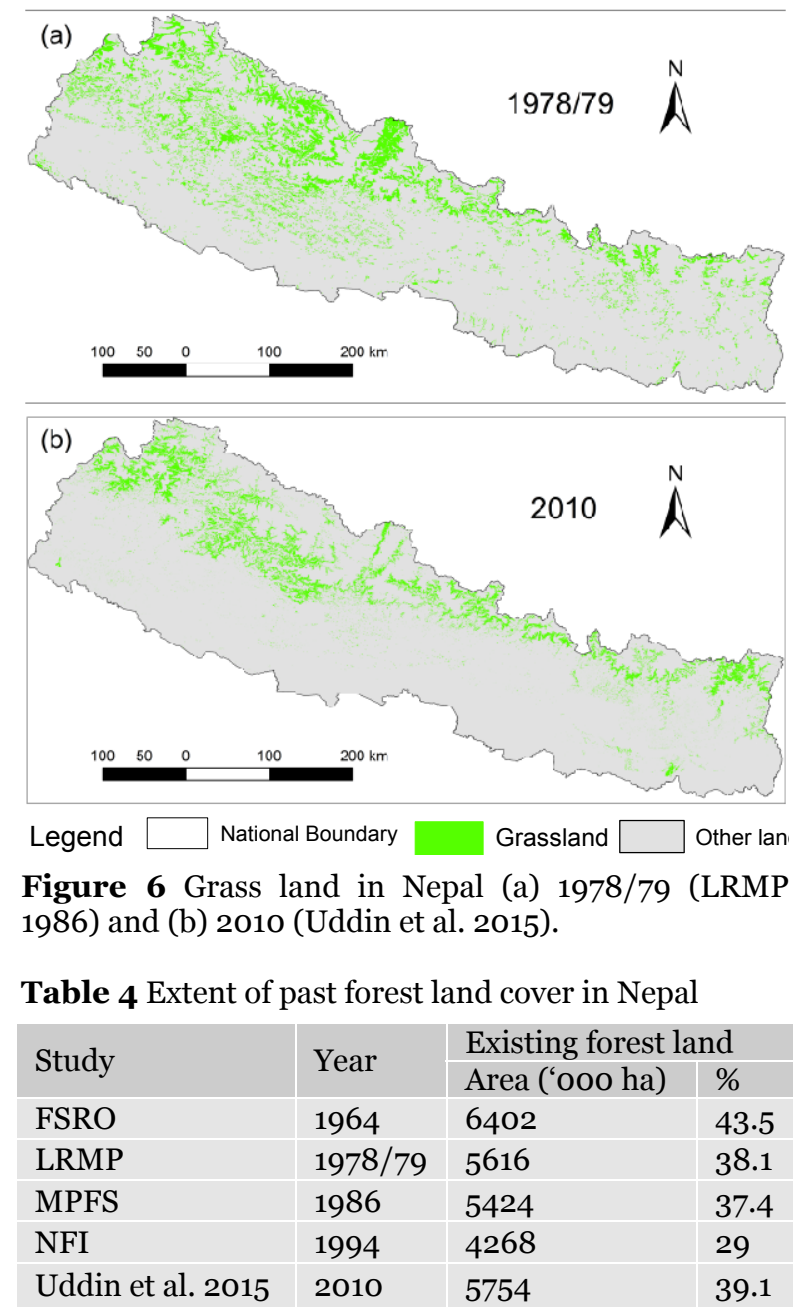


1986). In this period (1964-1978/79), forestland change (shrinkage) was $5.4 \%$. The study of MPFS shows that the percentage of forestland in 1986 was $37.4 \%$, which fell to $29 \%$ in $1990 / 91$ according to the NFI report (Gautam et al. 2004). Over these 30 years (1964-1994) forest land declined by almost 14.5 percentage points ( $43.5 \%$ to $29 \%$ ). However, a recent satellite-based national study (Uddin et al. 2015) reported that forest land in Nepal, which was $39.1 \%$ in 2010, had almost recovered to the level existing 46 years previously (Figure 7b).

Forest in the Tarai area decreased at an annual rate of $1.3 \%$ from $1978 / 79$ to $1990 / 91$, and from $1978 / 79$ to 1994 the decrease was $2.3 \%$ in the hills (Gautam et al. 2004). Similarly, nationally, forest area decreased by $1.7 \%$ annually between $1978 / 79$ and 1994. In contrast to the FAO datasets (FAO 2014), national-level research indicated a rapid decrease in forest land between 1964 and 1994, followed by a slight increase until 2010. This does not match FAO datasets, in which forest land is shown to decrease until 2010 (Figure 8). There is a vast gap between the two datasets, so further research is needed before considering a set of standard rules for studies of forest land change in Nepal.

\section{Urban land change}

Urban land change correlates with the process of urbanization, an important part of which is growth of the proportion of the population living in urban areas (Li and Lian 2012). Concepts of urban land change and expansion have been historically related to the economic development, specialization and industrialization that accompany them (Sharma 2003). While this relationship remains contested, there is a general consensus among researchers that a basic feature of an urban area is the structural shift in employment from agriculture to non-agricultural activities (Geyer and Kontuly 1993). Similarly, urban land expresses a territorial response to structural changes in the economy ( $\mathrm{Wu} 2002)$. The division of labor, modern technology-based goods and production, good services and a wide variety of goods, intense interaction of spatial and economic activities, and high population density are all fundamental aspects of urban areas. Accordingly, urban land change, or urbanization, is often taken as a proxy for the level of development (Sharma 1989; 2003).
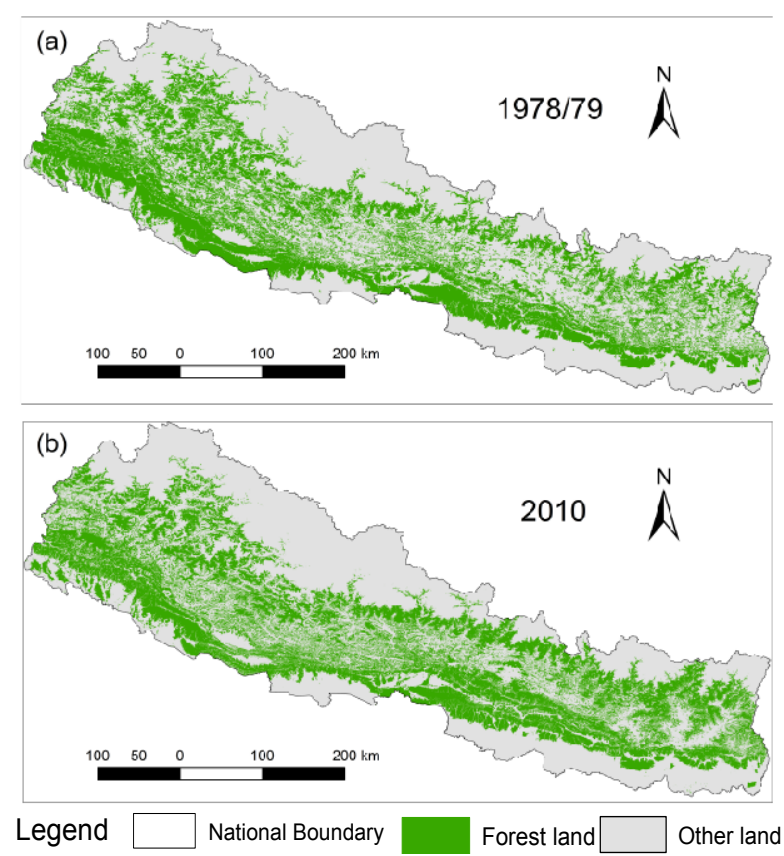

Figure 7 Forest land in Nepal (a) 1978/79 (LRMP 1986) and (b) 2010 (Uddin et al. 2015).

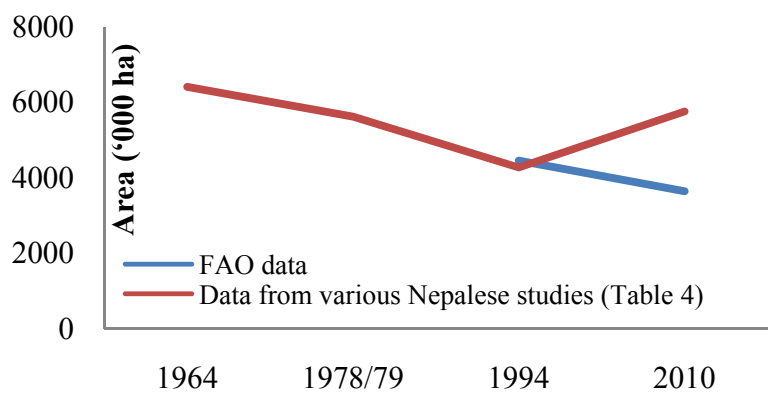

Figure 8 Forest land in Nepal 1964-2010.

Nepal is known as one of the least urbanized countries in South Asia, and in the world (Sharma 2003). The low level of urbanization is a major concern for its economic development (Poudel 2013). Various factors such as the diversification of agriculture, issues of ethnicity and gender, and employment opportunities are involved in the urban land change process (Bastola 1995). The form and nature of urban development in Nepal are open to debate, as urbanization has an agenda of partial internal development, which some would challenge (Sharma 2003). Current research defines urban land as the area of built-up territory in Nepal, according to the similar criteria of LRMP (1986) and Uddin et al. (2015). Between 1978/79 and 2010, there has been a rapid increase in the urban area of Nepal (LRMP 1986; Uddin et al. 2015). This was 
clarified by the satellite-based study of urban growth in Kathmandu valley between 1991 and 2010 and model-based prediction up to 2050 (Thapa and Murayama 2012). In 1978/79, there was a much smaller area of urban land, covering only $122 \mathrm{~km}^{2}$ (LRMP 1986) (Figure 9a). The rate of urban land expansion over the past 30 years has increased fourfold, with urban land covering a total $469 \mathrm{~km}^{2}$ in 2010 (Uddin et al. 2015), which was $0.32 \%$ of the country (Figure 9b). Urban land expansion is occurring in the Tarai region at a rapid rate, as well as in some major cities in the Hill region (Kathmandu, Pokhara, etc), where there is transportation together with market and service centers.

\section{Snow/glacier cover change}

Snow cover and glacier change is one of the major types of LUCC in Nepal and the hottest topic due to climate change in the Himalayan region; 'snow/glacier area' means land covered by snow and glacier. In recent decades, snow/glacier cover has rapidly changed in the mountainous regions. An Intergovernmental Panel on Climate Change (IPCC) report shows that the global annual mean temperature increased by $0.74^{\circ} \mathrm{C}$ over the past 100 years (IPCC 2001), where as in Nepal the temperature increased by between $0.15^{\circ} \mathrm{C}$ and $0.6^{\circ} \mathrm{C}$ every ten years in 1971-1994 (Shrestha et al. 1999), which was approximately two to eight times higher than the IPCC prediction (Bajracharya et al. 2014). On the basis of these analyses, snow/glacier cover changes in Nepal's mountainous regions are proceeding rapidly. This has been verified by the Himalayan region annual glacier retreat rate, reported as $0.3^{-1 \mathrm{~m}}$, the highest rate in the world (Dyurgerov and Meier 2005). Many studies (regional, national and small-scale) have been carried out on Nepal's snow/glacier cover changes (Fujita et al. 1997; Kadota et al. 1997; Nie et al. 2010; Bajracharya et al. 2011; Lamsal et al. 2011; Maskey et al. 2011; Bolch et al. 2012; Bajracharya et al. 2014), which all examine the changing situation of snow/glacier cover in the country.

In 1978, the status of snow/glacier cover was $5284.12 \mathrm{~km}^{2}$ (LRMP 1986) (Figure 10a); it was $5168.3 \mathrm{~km}^{2}$ in 1980, $4506.3 \mathrm{~km}^{2}$ in 1990, 4210.9 $\mathrm{km}^{2}$ in 2000 and $3902.4 \mathrm{~km}^{2}$ in 2010 (Bajracharya et al. 2014). Overall snow cover between 1980 and 2010 has been decreased by $24 \%$. Another study of snow/glacier cover showed that the area covered $5323.9 \mathrm{~km}^{2}$ in 2001 and $4212.03 \mathrm{~km}^{2}$ in 2010 (Bajracharya et al. 2011). For the period 2000-
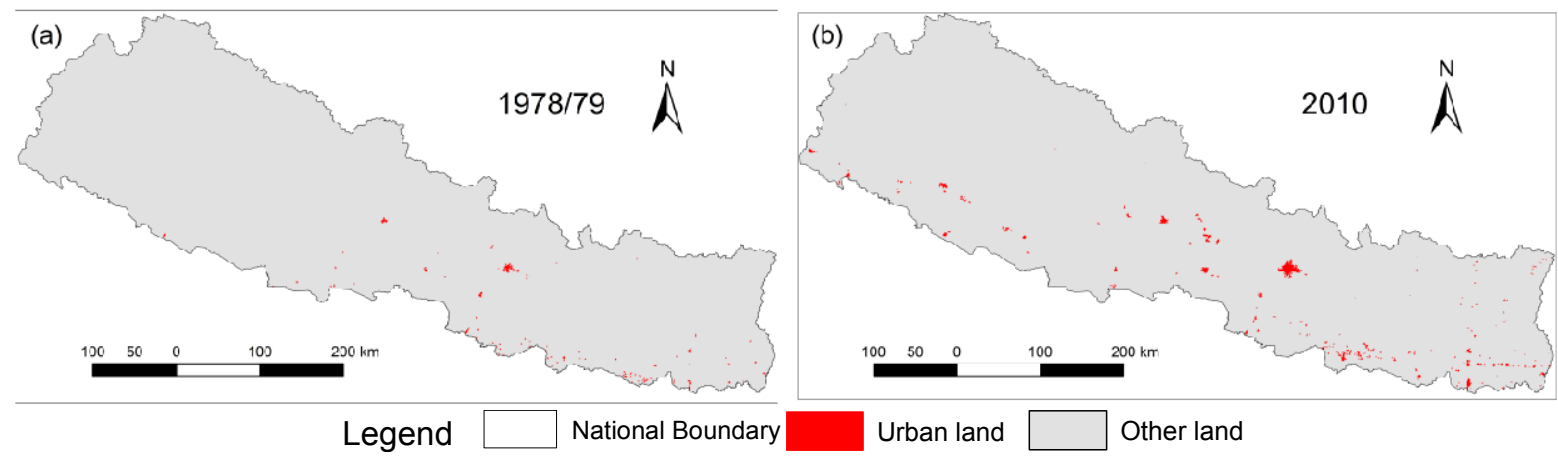

Figure 9 Urban land change in Nepal (a) 1978/79 (LRMP 1986) and (b) 2010 (Uddin et al. 2015).
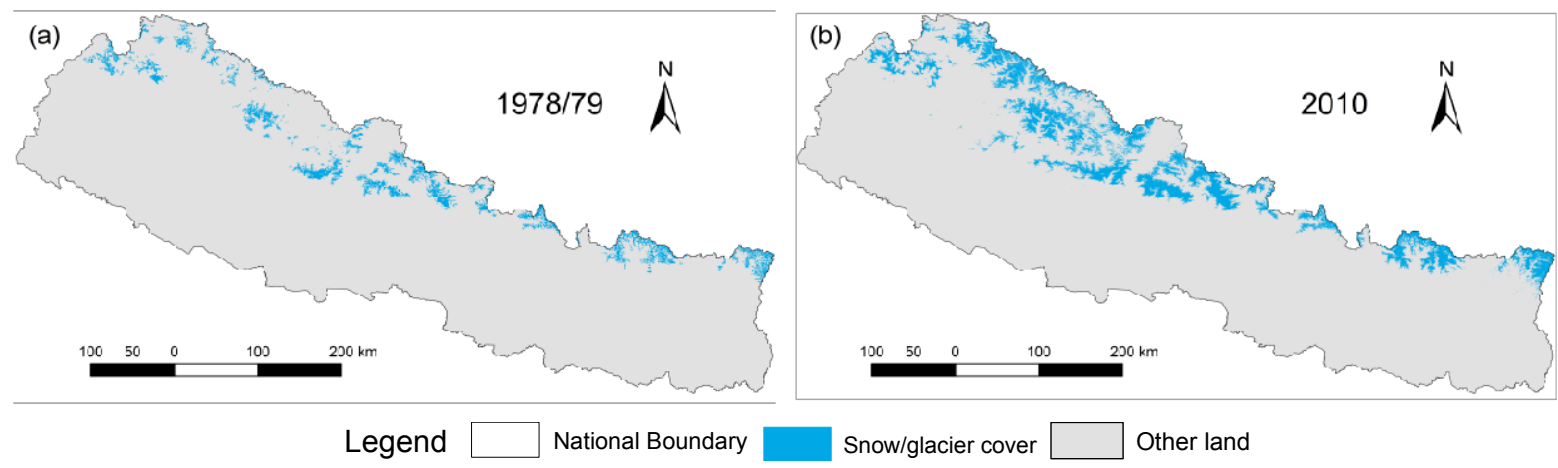

Figure 10 Status of snow and glacier cover in 1978/79 (a) (LRMP 1986) and 2010 (b) (Uddin et al. 2015). 
Table 5 Landsat TM/ETM+ based major Land use and land cover (LULC) statistics (National and Global) of Nepal in 2010

\begin{tabular}{l|l|l|l|l|l|}
\hline \multirow{2}{*}{ LULC types } & \multicolumn{2}{l}{ National (Uddin et al. 2015) } & \multicolumn{2}{l|}{ Global (Chen et al. 2015) } & (National to Global) \\
\cline { 2 - 5 } & Area $\left(\mathrm{km}^{2}\right)$ & $\%$ & Area $\left(\mathrm{km}^{2}\right)$ & $\%$ & Differences $\left(\mathrm{km}^{2}\right)$ \\
\hline Forestland & 57,538 & 39.1 & $67,165.16$ & 45.63 & +9627.16 \\
\hline Cropland & 43,910 & 29.83 & 45,098 & 30.64 & +1188 \\
\hline Grassland & 11,634 & 7.90 & $26,510.41$ & 18.01 & $+14,876.41$ \\
\hline Snow/glacier cover & 12,062 & 8.20 & 5362.35 & 3.64 & -6699.65 \\
\hline Other & 22,037 & 14.97 & 3045.08 & 2.08 & $-18,991.92$ \\
Total & 147,181 & 100 & 147,181 & 100 & \\
\hline
\end{tabular}

2005, a national-level study reported that areas of $41019 \mathrm{~km}^{2}, 3739 \mathrm{~km}^{2}$ and $13,546 \mathrm{~km}^{2}$ were covered by snow in 2000, (these being the maximum, minimum and mean areas) and areas of $53,012 \mathrm{~km}^{2}, 3219 \mathrm{~km}^{2}$ and $17,938 \mathrm{~km}^{2}$ were covered in 2005 (Shrestha and Joshi 2009). Different studies present different figures for snow/glacier cover for the same year (2010): a 2011 study (Bajracharya et al. 2011) gave a figure of 4212.03 $\mathrm{km}^{2}$; in 2014 a study (Bajracharya et al. 2014) gave a figure of $3902.4 \mathrm{~km}^{2}$; and a 2015 study (Uddin et al. 2015) reported that snow/glaciers covered $12,062 \mathrm{~km}^{2}$ (8.20\% of the country) (Figure 10b). This indicates that research results vary according to the methods, modeling and seasonal-based satellite images used.

Glaciers and snow cover in the central Himalaya region are summer accumulations (Bolch et al. 2012), which means that LUCCs in mountainous regions in Nepal vary according to the seasons. The MODIS base snow cover seasonal mapping shows the trend of snow cover rate decreasing in January and increasing in March between 2000 and 2008 (Maskey et al. 2011), although significant errors in estimating seasonal snow cover occurred because of cloud during the period of analysis (Shrestha and Joshi 2009). The historical age of ice glaciations in Nepal's various mountains has been well documented (Kuhle 2006a; b), while another study of snow cover covering 30 years (1978-2009) in the Sagarmatha (Everest) National park area identified an increasing trend, where snow cover was $34.2 \%$ in 1978 and 39.8\% in 2009 (Midriak 2009). However, model-based research shows that the Dudh Koshi basin of the Everest region in Nepal had rapidly reduced glaciations from 1996 to 2007, and according to these results the glacier volume will have reduced by $73 \%-96 \%$ by 2100 (Shea et al.
2014). Results of research into overall snow/glacier cover change show that the snow cover area in Nepal is rapidly decreasing; this is a fact directly related to rising temperature and climate change.

\section{Comparison between National and Global Datasets}

There are several global-(Goldewijk 2001; Goldewijk and Ramankutty 2004; Goldewijk et al. 2011; Gong et al. 2013; Chen et al. 2015) and national-level (LRMP 1986; Uddin et al. 2015) studies on LULC by various researchers from different institutions for different periods. However, in this paper, comparisons were carried out between the studies of Uddin et al. (2015) and Chen et al. (2015), which represent national-level and global-level studies, respectively. These two studies (National and Global), with their major LULC classes, were chosen because they both used the same data sources and period. The study of Uddin et al. (2015) used a Landsat TM dataset of baseline year 2010; similarly, Chen et al. (2015) also used Landsat TM/ETM+ satellite imagery of the same baseline year for a global land cover study. Table 5 shows the vast differences between the two datasets, which means that the global-level framework of Landsat TM/ETM+ based land cover research needs to be harmonized with nationalscale inputs for more reliable global land cover datasets. Comparison of global-scale study with the national-level study they produced quite similar values for area of cropland cover, while the results for the other major land cover categories are far from those from the national-level study of Nepal.

The comparison of forest cover between these two datasets for 2010 revealed a significant difference $57,538 \mathrm{~km}^{2}$ (39.1\% of the country) for 
the national dataset (Figure 11a) and $45098 \mathrm{~km}^{2}$ (45.63\% of the country) for the global dataset (Figure 11b). Similarly, the national-level research reported cropland in Nepal as being $29.83 \%$ $\left(43910 \mathrm{~km}^{2}\right)$ (Figure 11c), while the global-level study gave a value of $30.64 \%\left(45098 \mathrm{~km}^{2}\right)$ of the country (Figure 11d). The comparison of grassland and snow/glacier cover for the national study (Uddin et al. 2015) and the global study (Chen et al.
2015) showed that the results from the nationallevel study were more accurate. There were significant differences in the grassland figures, at $11634 \mathrm{~km}^{2}(7.90 \%)$ and $26510.41 \mathrm{~km}^{2}(18.01 \%)$ for the national and global studies, respectively (Figure $11 \mathrm{e}$ and 11f), which was $14876.41 \mathrm{~km}^{2}$ more grassland for the global study than for the national study. The comparison of snow/glacier cover is quite different from other land categories. For this
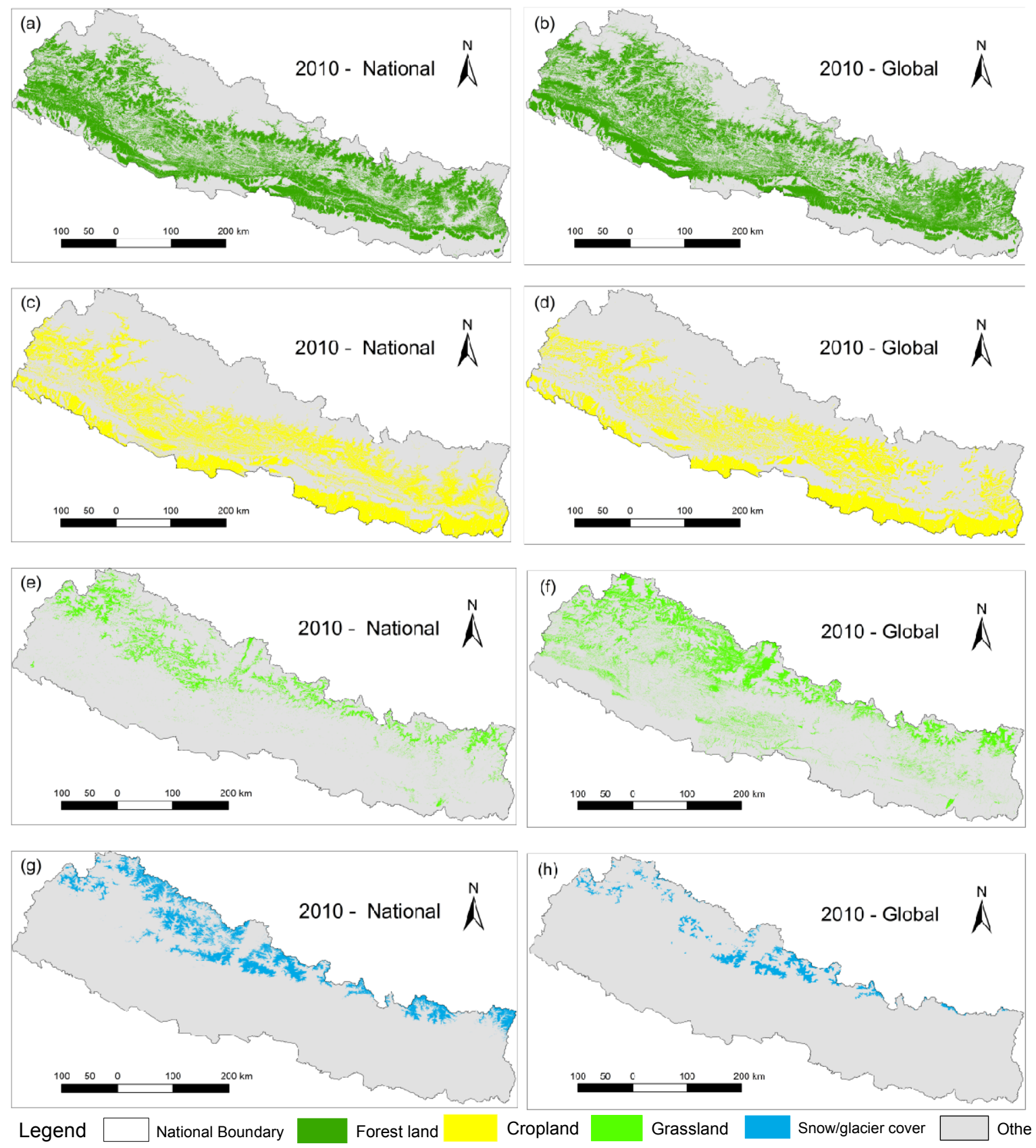

Figure 11 National (Uddin et al. 2015) and global (Chen et al. 2015) datasets based major Land use and land cover (LULC) status of 2010 in Nepal. 
category, the national-scale research result was $8.20 \%\left(12,062 \mathrm{~km}^{2}\right)$ of the country (Figure $11 \mathrm{~g}$ ), which differs significantly several other nationallevel studies (Bajracharya et al. 2011; Bajracharya et al. 2014). In this context, the result from global study is more similar than that from the national study, and gave a value of $3.64 \%\left(5362.35 \mathrm{~km}^{2}\right)$ snow/glacier cover in Nepal for 2010 (Figure 11h), $6699.65 \mathrm{~km}^{2}$ less than that national-level study.

The vast differences between national and global studies may have risen due to the methodologies adopted for classification of different LULC, verified validation of ground truth, and data validation and accuracy assessment for the work. The comparison illustrates (Table 5) a significant difference in grassland and snow/glacier cover classification and scope for the improvement of global LULC products, especially in relation to the misclassification of grassland, shadow areas, cropland, shrub land and forest cover (Fuller et al. 2003). To do this, the nationallevel study developed specific signatures and used local level field data to improve such misclassifications (Uddin et al. 2015). Similarly, for accurate mapping of shrub land, they adapted multi-season TM satellite data and developed an online crowd-source-based validation tool to obtain public forum feedback for better accuracy. These types of tools helped to improve the nonavailability of high-resolution and multi-season Landsat TM data and lack of ground-based truth due to remoteness (Uddin et al. 2015). They used 435 Google Earth derived reference points and 130 GPS-tagged field validation points for accuracy assessment. However, the global-level study has developed pixel-based and object-based methods with knowledge (POK-based), together with webbased reference data integration, knowledge-based interactive verification and hybrid pixel and objectbased classification. They claim that an overall classification accuracy of global land cover monitoring achieved over $80 \%$. The global LULC made a great contribution; but when comparing this with national LULC datasets, there were large differences, and the global LULC was far removed from the real situation of local LULC. Therefore, we recommend the adoption of national LULC datasets for national-level and local-level studies such as climatic modeling or carbon cycles.

\section{Problems and Discussion}

\subsection{Problems}

Previous researchers have paid little attention to long-term historical LUCC studies in Nepal. The lack of previous research and historical data makes it very difficult to study historical LUCC in Nepal. Similarly, other related proxies, and data on population, climate and land tax, have been available for only a short period; such datasets are an essential part of studying historical LUCC. Before the 1960s, the LULC research sector in Nepal had the problem of a lack of spatial historical datasets. In recent years, some data have been available for forest and cropland but not on a systematic basis. There have been different internal administrative boundaries in Nepal for different periods, which means that it can be difficult to reconcile internal boundaries and different types of data. The available datasets are in different formats: some are spatial and digital, and some are statistical and in hard copy format. Researchers therefore need to spend a lot of time converting statistical data into spatial and digital formats and on reconstruction. In 1986, Nepal's first detailed spatial LULC datasets of LRMP were created by the Government of Nepal fusing aerial photographs from $1978 / 79$, while recently one national land cover dataset for 2010 was prepared by Uddin et al. (2015) using Landsat 5TM $30 \mathrm{~m}$ resolution satellite images. These two datasets used different sources, resolutions and techniques, which means that they are not a very good interpretation of the chosen the LUCC area. Another important problem is scale mismatch between various datasets. Such problems need to be addressed by future researchers wishing to conduct long-term historical LUCC studies of Nepal.

\subsection{Discussion}

The available historical data and research for cropland, forest, grassland, urban land and snow/glacier cover show past LULC conditions, which were directly related to the human population and to ecological systems, while national-level long-term datasets and studies of LULC are relatively scarce except for those on a global scale. LULC spatial coverage in the historical archives is almost non-existent before the 1960s. 
Detailed spatial datasets at the national level are available for certain periods (LRMP 1986; Uddin et al. 2015) as a sector of LULC in Nepal. It is interesting to point out that the definition of LULC classification varies between studies and dataset extensions, especially when it is not possible to combine information satisfactorily. The results of various studies therefore highlight the fact that uncertainties and gaps in temporal and spatial changes are the greatest challenges for estimation of accurate historical LUCC.

Global-level historical and recent datasets and studies (Ramankutty and Foley 1999; Goldewijk et al. 2011; Gong et al. 2013; Chen et al. 2015) have steadily developed available information on LUCC in Nepal, but their results and findings show vast differences between national-level total spatial and statistical distribution of LULC areas in Nepal. National and small-scale studies are based on historical documents, and they provide only improved explanations and information for historical LULC conditions; none of them provide spatial patterns and datasets. Since the 1960s, there have been spatial datasets for various sectors of LULC in Nepal, but resolution is generally low and collecting and translating that information into LULC types is not a simple task. It is essential that various techniques and more resources should be devoted to achieving better reconstruction of Nepal's historical LUCC.

Each land category has its individual driving factors (Goldewijk 2001). However, the review of historical documents shows that there is a correlation with regard to land use patterns and distribution of total areas. Research indicates that some periods have been characterized by anticorrelation between cropland and forest areal extent, shown for different time periods by a rapid increase in cropland area and an unprecedented rate of decreased forest area. Land use policies are also helping to change the direction and future trends of LUCC. The dynamics of Earth systems are always interesting: not only do they involve the complexity of the biophysical and socioeconomic drivers of LUCC but also the human and climatic conditions of such changes are very significant. Figures 4 to 6 illustrate crop and grassland trends in Nepal from historical to present day, while Figure 9 shows trends of urban expansion, Figure 10 shows the status of snow/glacier cover, and
Figures 7 and 8 show forest scenarios up to 2010, indicating their close interrelationship. Similarly, Figure 11 gives us an idea of how significant the differences are between global and national LULC studies. An accurate estimation of historical research and data is crucial for the status of historical LUCC, since most inverse models rely heavily on the mechanisms of human environment interactions, which still require intensive research.

\section{Conclusions}

The study of historical LUCC in Nepal is relevant to research into cropland evolution, forest and grassland degradation, snow/glacier cover change and urban land expansion, which have been given more attention in recent decades. The present study aimed to review available LULC research, datasets and documents relevant to the past status in Nepal, especially the changing scenarios of cropland, grassland, forest, urban land and snow/glacier cover areas. The statistical datasets indicate that the area of cropland in Nepal years increased by $13 \%$ over the past 50 years, while spatial datasets for 1978 to 2010 show that the area grew to $2.64 \%$ of the country. The changing trend for forest land is quite different from that far cropland. The change in status of forest land in Nepal has been dramatic over the past 46 years. It covered $43.5 \%$ of the country's area in the 1960 s, but rapidly reduced to $29 \%$ in the 1990 s, and recently recovered to $39.1 \%$ in the 2010s. Grassland has decreased overall, while urban land has increased rapidly over the past 32 years (from $122 \mathrm{~km}^{2}$ to 469 $\mathrm{km}^{2}$ ). The status of change in snow/glacier area reported by most research is a high rate of shrinkage from past times to recent decades, and it is predicted that this will continue at a rapid rate in the future. However, having reviewed numerous studies, we can conclude that the estimation of historical LUCC is always open to challenge because of the high levels of uncertainty and knowledge gaps regarding temporal and spatial changes. Most of the information accessed, and most archives, relate to forest and snow/glacier cover change. Further LUCC research is required to develop better ways of combining various historical and current methods and data sources, especially to integrate available global data into national studies and to correlate 
environmental conditions and human activity.

\section{Acknowledgements}

This work was supported by the Natural Science Foundation of China (Grant No. 41371120); the Koshi Basin Programme (Support from the Australian Government through the Department of Foreign Affairs and Trade (DFAT)); and the

\section{References}

Acharya K, Dangi R (2009) Case studies on measuring and assessing forest degradation: forest degradation in Nepal: review of data and methods. Rome, Italy. p 163.

Armstrong RL (2010) The glaciers of the Hindu KushHimalayan region: a summary of the science regarding glacier melt/retreat in the Himalayan, Hindu Kush, Karakoram, Pamir, and Tien Shan mountain ranges. International Centre for Integrated Mountain Development (ICIMOD). p 16.

Bajracharya D (1983) Deforestation in the food/fuel context: historical and political perspectives from Nepal. Mountain Research and Development 3(3): 227-240.

Bajracharya S, Maharjan S, Shrestha F, et al. (2014) Glacier Status in Nepal and Decadal Change from 1980 to 2010 Based on Landsat Data. ICIMOD, Kathmandu, Nepal. p 88.

Bajracharya SR, Shrestha B (2011) The status of glaciers in the Hindu Kush-Himalayan region. International Centre for Integrated Mountain Development (ICIMOD). p 127.

Bajracharya SR, Shrestha F, Maharjan SB (2011) Glaciers shrinking in Nepal Himalaya. INTECH Open Access Publisher. p 458.

Bastola TS (1995) Urbanization. Population Monograph of Nepal. pp 239-300.

Becker A, Bugmann H (2001) Global change and mountain regions - an IGBP initiative for collaborative research. In: Visconti $\mathrm{G}$ et al. (eds.), Global Change and Protected Areas. Advance in Global Change Research. Laquila, Italy. pp 3-9.

Bishop BC (1990) Karnali under stress: livelihood strategies and seasonal rhythms in a changing Nepal Himalaya. University of Chicago. p 460.

Bolch T, Kulkarni A, Kääb A, et al. (2012) The state and fate of Himalayan glaciers. Science 336(6079): 310-314. DOI: $10.1126 /$ science. 1215828

CBS (2012) National Population and Housing Census 2011 (National Report). Government of Nepal, National Planning Commission Secretariat. Central Bureau of Statistics, Kathmandu, Nepal. p 264.

Chen J, Chen J, Liao A, et al. (2015) Global land cover mapping at 30m resolution: A POK-based operational approach. ISPRS Journal of Photogrammetry and Remote Sensing 103: 7-27. DOI: $10.1016 /$ j.isprsjprs.2014.09.002

Chhatkuli RR (2004) National Geographic Information Infrastructure in Nepal for Strengthening Planning and Resource Management. Nepalese Journal on Geoinformatics 3: 1-9.

Collins R, Jenkins A (1996) The impact of agricultural land use on stream chemistry in the Middle Hills of the Himalayas, Nepal. Journal of Hydrology 185(1): 71-86. DOI: 10.1016/ o022-1694(95)03008-5

Dyurgerov MB, Meier MF (2005) Glaciers and the changing earth system: a 2004 snapshot. Institute of Arctic and Alpine Research, University of Colorado Boulder. p 117.

FAO (2014) FAO Statistical Yearbook 2014, Asia and the Pacific
Chinese Academy of Sciences - The World Academy of Sciences (CAS-TWAS) President's Fellowship Programme for international $\mathrm{PhD}$ students. We are extremely grateful to Mr. Basanta Raj Shrestha, Dr. Arun Bhakta Shrestha, Dr. SM Wahid and Dr. MSR Murthy of ICIMOD, Nepal, for sharing their valuable datasets and comments. The authors are grateful for the constructive comments from the editor and anonymous reviewers.
Food and Agriculture. Food and Agriculture Organization of the United Nations Regional Office for Asia and the Pacific. Bangkok. p 176.

Fox J (1993) Forest resources in a Nepali village in 1980 and 1990: the positive influence of population growth. Mountain Research and Development 13(1): 89-98. DOI: 98.10.2307/ 3673646

FRA (2010) Global Forestry Resources Assessment 2010, Country Report, Nepal. Food and Agriculture Organization of the United Nations. The Forest Resources Assessment Programme,Rome. p 56.

Fujita K, Nakawo M, Fujii Y, et al. (1997) Changes in glaciers in hidden valley, Mukut Himal, Nepal Himalayas, from 1974 to 1994. Journal of Glaciology 43(145): 583-588.

Fuller RM, Smith GM, Devereux BJ (2003) The characterisation and measurement of land cover change through remote sensing: problems in operational applications? International Journal of Applied Earth Observation and Geoinformation 4(3): 243-253. DOI:10.1016/So303-2434(03)oooo4-7

Gao J (2012) Land cover change and its relationship with climate chage in Koshi River Basin of central Himalaya. Institute of Geographic Sciences and Natural Resources Research, Graduate University of Chinese Academy of Sciences. p 160.

Gautam A, Shivakoti G, Webb E (2004) A review of forest policies, institutions, and changes in the resource condition in Nepal. International forestry review 6(2): 136-148. DOI: 10.1505/ifor.6.2.136.38397

Gautam AP, Webb EL, Shivakoti GP, et al. (2003) Land use dynamics and landscape change pattern in a mountain watershed in Nepal. Agriculture, Ecosystems \& Environment 99(1): 83-96. DOI: 10.1016/s0167-8809(03)00148-8

Geyer HS, Kontuly T (1993) A theoretical foundation for the concept of differential urbanization. International Regional Science Review 15(2): 157-177. DOI: 10.1177/01600176930 1500202

Gilmour DA, Fisher RJ (1991) Villagers, forests and foresters: The philosophy, process and practice of community forestry in Nepal. Sahayogi Press Kathmandu, Nepal. p 212.

Goldewijk KK (2001) Estimating global land use change over the past 300 years: The HYDE Database. Global Biogeochemical Cycles 15(2): 417-433. DOI: 10.1029/1999GBo01232

Goldewijk KK, Beusen A, Van Drecht G, et al. (2011) The HYDE 3.1 spatially explicit database of human-induced global land-use change over the past 12,00o years. Global Ecology and Biogeography 20(1): 73-86. DOI: $10.1111 / \mathrm{j} .1466-8238$. 2010.00587.x

Goldewijk KK, Ramankutty N (2004) Land cover change over the last three centuries due to human activities: the availability of new global data sets. GeoJournal 61(4): 335344 .

Goldewijk KK, Verburg PH (2013) Uncertainties in global-scale 
reconstructions of historical land use: an illustration using the HYDE data set. Landscape ecology 28(5): 861-877. DOI: 10.1007/s10980-013-9877-x

Gong P, Wang J, Yu L, et al. (2013) Finer resolution observation and monitoring of global land cover: first mapping results with Landsat TM and ETM+ data. International Journal of Remote Sensing 34(7): 2607-2654. DOI: 10.1080/01431161. 2012.748992

Houghton RA (2003) Revised estimates of the annual net flux of carbon to the atmosphere from changes in land use and land management 1850-2000. Tellus B 55(2): 378-390. DOI: 10.1034/j.1600-0889.2003.01450.x

Hua XB, Yan JZ, Liu X, et al. (2013) Factors influencing the grazing management styles of settled herders: a case study of Nagqu County, Tibetan Plateau, China. Journal of Mountain Science 10(6): 1074-1084. DOI: 10.1007/s11629-013-2726-1

IPCC (2001) Climate change 2001: Technical Summary, Contribution of Working Group I to the Third Assessment Report of the Intergovernmental Panel on Climate Change. Cambridge University Press, Cambridge, UK. p 881.

Ives JD, Messerli B (1989) Himalayan Dilemma. United Nations University Press, New York. p 295.

Kadota T, Fujita K, Seko K, et al. (1997) Monitoring and prediction of shrinkage of a small glacier in the Nepal Himalaya. In: Whillans IM (eds.). Annals of Glaciology 24: 90-94.

Katwal B, Sah L (1992) Transformation of mountain agriculture: case study. International Centre for Integrated Mountain Development (ICIMOD), Nepal. p 79.

Keyser JD, Kaiser DA (2010) Getting the Point: Metal Weapons in Plains Rock Art. Plains Anthropologist 55(214): 111-132.

Khanal N (2002) Land Use and Land Cover Dynamics in the Himalaya: A Case Study of the Madi Watershed, Western Development Region, Nepal. Tribhuvan University, Kirtipur, Nepal. p 297.

Khanal NR, Watanabe T (2006) Abandonment of agricultural land and its consequences. Mountain Research and Development 26(1): 32-40. DOI: 10.1659/0276-4741(2006) 026[0032:AOALAI]2.0.CO;2

Kirkpatrick WJ (1996) An Account of the Kingdom of Nepaul. Asian Educational Services. p 386.

Kuhle M (2006a) Reconstruction of the Ice Age glaciation in the southern slopes of Mt. Everest, Cho Oyu, Lhotse and Makalu (Himalaya) (Part 1). Journal of Mountain Science 3(2): 91-124. DOI: $10.1007 / \mathrm{s} 11629-006-0091-\mathrm{Z}$

Kuhle M (2006b) Reconstruction of the ice age glaciation in the southern slopes of Mt. Everest, Cho Oyu, Lhotse and Makalu (Himalaya) (Part 2). Journal of Mountain Science 3(3): 191227. DOI: $10.1007 / \mathrm{s} 11629-006-0191-9$

Kuhle M (2014) The glacial (MIS 3-2) outlet glacier of the Marsyandi Nadi-icestream-network with its Ngadi Khola tributary glacier (Manaslu-and Lamjung Himalaya): The reconstructed lowering of the Marsyandi Nadi ice stream tongue down in to the southern Himalaya Foreland. Journal of Mountain Science 11(1): 236-287. DOI: 10.1007/s11629013-2820-4

Lamsal D, Sawagaki T, Watanabe T (2011) Digital terrain modelling using Corona and ALOS PRISM data to investigate the distal part of Imja Glacier, Khumbu Himal, Nepal. Journal of Mountain Science 8(3): 390-402. DOI: 10.1007/s11629011-2064-0

Li C, Lian L (2012) Theoretical Research of the Urban Comprehensive Carrying Capacity in the Epoch of Urbanization. International Journal of Financial Research 3(1): 105-113. DOI: $10.5430 /$ ijfr.v3n1p105

LRMP (1986) Land Utilization Report. Land Resource Mapping Project, Kenting Earth Science Canada and Department of Topography, Government of Nepal, Kathmandu, Nepal. p 112.

Mahat T, Griffin D, Shepherd K (1986) Human Impact on Some Forests of the Middle Hills of Nepal Part 2. Some Major Human Impacts before 1950 on the Forests of Sindhu Palchok and Kabhre Palanchok. Mountain Research and Development
6(4): 325-334. DOI: $10.2307 / 3673373$

Mahat TBS (1985) Human impact on forests in the middle hills of Nepal. Australian National University. Canberra.

Mahat TBS (1987) Forestry-farming linkages in the mountains. International Centre for Integrated Mountain Development (ICIMOD), Nepal. p 48.

Malla YB (2000) Impact of community forestry policy on rural livelihoods and food security in Nepal. Unasylva (English ed.) 51(202): 37-45

Marsh GP (1864) Man and nature. University of Washington Press, p 512.

Maskey S, Uhlenbrook S, Ojha S (2011) An analysis of snow cover changes in the Himalayan region using MODIS snow products and in-situ temperature data. Climatic Change 108(1-2): 391-400. DOI: 10.1007/s10584-011-0181-y

Midriak R (2009) Changes of glaciation in the Sagarmatha National Park (Nepal) during the last 30 years. Landform Analysis 10: 85-94.

MoFSC (2009) Asia-Pacific Forestry Sector Outlook Study II: Nepal Forestry Ootlook Study. Ministry of Forests and Soil Conservation. Singha Durbar, Kathmandu, Nepal. p 83.

MPFS (1989a) Master Plan for Forestry Sector, Main Report. Ministry of Forestry and Soil Conservation, Kathmandu, Nepal.

MPFS (1989b) Master Plan for Forestry Sector, Forestry Resource Information and Planning Report. Ministry of Forestry and Soil Conservation, Kathmandu, Nepal.

Nie Y, Zhang Y, Liu L, et al. (2010) Glacial change in the vicinity of Mt. Qomolangma (Everest), central high Himalayas since 1976. Journal of Geographical Sciences 20(5): 667-686. DOI: 10.1007/s11442-010-0803-8

Nield R (1985) Fuelwood and fodder-problems and policy. Water and Energy Commission Secretariat. Kathmandu, Nepal. p 44.

Pongratz J, Reick C, Raddatz T, et al. (2008) A reconstruction of global agricultural areas and land cover for the last millennium. Global Biogeochemical Cycles 22(3): 1-16. DOI: 10.1029/2007GBoo3153

Poudel KP (2013) National Development Plan and Urbanization in Nepal. 12th International Asian Urbanization Conference on Urban Dynamics, Environment and Health: Challenges for the Twenty First Century. Department of Geography, Banaras Hindu University, India. pp 1-16.

Ramankutty N, Foley JA (1999) Estimating historical changes in global land cover: Croplands from 1700 to 1992. Global Biogeochemical Cycles 13(4): 997-1027. DOI: 10.1029/ 1999 GB900046

Regmi MC (1976) Landownership in Nepal. University of California Press, Berkeley. p. 252.

Regmi MC (1978) Land Tenure and Taxation in Nepal. Ratna Pustak Bhandar, Kathamandu, Nepal. p 895

Rokaya MB, Muenzbergova Z, Shrestha MR, et al. (2012) Distribution patterns of medicinal plants along an elevational gradient in central Himalaya, Nepal. Journal of Mountain Science 9(2): 201-213. DOI: 10.1007/s11629-012-2144-9

Sharma B (2006) The Role of Pasture and Fodder Development Programme for Landless Farmer in Degraded Forest Land of Mid and High Hills of Nepal. Agriculture and Environment. Agri-Environment and Biodiversity Section, Ministry of Agriculture and Cooperatives, Singh Durbar, Kathmandu, Nepal. pp 89-99.

Sharma KP, Vorosmarty CJ, Moore Iii B (2000) Sensitivity of the Himalayan hydrology to land-use and climatic changes. Climatic Change 47(1-2): 117-139. DOI: 10.1023/ a:1005668724203

Sharma P (1989) Urbanization in Nepal. East West Population Institute, Honolulu, East West Centre. p 110.

Sharma P (2003) Urbanization and Development. Population monograph of Nepal. pp 375-412.

Shea J, Immerzeel W, Wagnon P, et al. (2014) Modelling glacier change in the Everest region, Nepal Himalaya. The Cryosphere Discussions 8(5): 5375-5432. DOI: $10.5194 /$ tcd-8- 
$5375-2014$

Shrestha AB, Joshi SP (2009) Snow cover and glacier change study in Nepalese Himalaya using Remote Sensing and Geographic Information System. Journal of Hydrology and Meteorology 6(1): 26-36.

Shrestha AB, Wake CP, Mayewski PA, et al. (1999) Maximum temperature trends in the Himalaya and its vicinity: An analysis based on temperature records from Nepal for the period 1971-94. Journal of climate 12(9): 2775-2786. DOI: 10.1175/1520-0442(1999)012<2775:MTTITH > 2.0.CO;2

Shrestha B, Brown S, (1995) Land Use Dynamics and Intensification. Challenges in Mountain Resources Management in Nepal-Processes, Trends, and Dynamics in Middle Mountain Watersheds. ICIMOD, Kathmandu, Nepal. pp 141-154.

Shrestha DP, Zinck JA (2001) Land use classification in mountainous areas: integration of image processing, digital elevation data and field knowledge (application to Nepal). International Journal of Applied Earth Observation and Geoinformation 3(1): 78-85. DOI: 10.1016/So303-2434(01) 85024-8

Shrestha M, Wang L, Koike T, et al. (2012) Modeling the spatial distribution of snow cover in the Dudhkoshi region of the Nepal Himalayas. Journal of Hydrometeorology 13(1): 204222. DOI: $10.1175 / J H M-D-10-05027.1$

Thapa GB (1996) Land use, land management and environment in a subsistence mountain economy in Nepal. Agriculture, Ecosystems \& Environment 57(1): 57-71. DOI: 10.1016/0167-
8809(96)88021-2

Thapa GB, Weber KE (1990) Managing mountain watersheds: The upper Pokhara valley, Nepal. Division of Human Settlements Development, Asian Institute of Technology. $p$ 326.

Thapa RB, Murayama Y (2012) Scenario based urban growth allocation in Kathmandu Valley, Nepal. Landscape and Urban Planning 105(1-2): 140-148. DOI: 10.1016/j.landurbplan. 2011.12.007

Uddin K, Shrestha HL, Murthy MSR, et al. (2015) Development of 2010 national land cover database for the Nepal. Journal of Environmental Management 148: 82-90. DOI: 10.1016/ j.jenvman.2014.07.047

Virgo K, Subba K (1994) Land-Use Change between 1978 and 1990 in Dhankuta District, Koshi Hills, Eastern Nepal. Mountain Research and Development 14(2): 159-170. DOI: $10.2307 / 3673798$

Whiteman PT (1985) The Mountain Environment: An Agronomist's Perspective with a Case Study from Jumla, Nepal. Mountain Research and Development 5(2): 151-162. DOI: $10.2307 / 3673254$

Wu F (2002) China's Changing Urban Governance in the Transition Towards a More Market-oriented Economy. Urban Studies 39(7): 1071-1093.DOI: 10.1080/00420980220135491

Zhang Y, Qi W, Zhou C, et al. (2014) Spatial and temporal variability in the net primary production of alpine grassland on the Tibetan Plateau since 1982. Journal of Geographical Sciences 24(2): 269-287. DOI: $10.1007 / \mathrm{s} 11442-014-1087-1$ 